The University of Maine

\title{
DigitalCommons@UMaine
}

Earth Science Faculty Scholarship

Earth Sciences

1995

\section{Bioarchaeological and Climatological Evidence for the Fate of Norse Farmers in Medieval Greenland}

P. C. Buckland

T. Amorosi

L. K. Barlow

A. J. Dugmore

Paul Andrew Mayewski

University of Maine, paul.mayewski@maine.edu

See next page for additional authors

Follow this and additional works at: https://digitalcommons.library.umaine.edu/ers_facpub

Part of the Anthropology Commons, and the Climate Commons

\section{Repository Citation}

Buckland, P. C.; Amorosi, T.; Barlow, L. K.; Dugmore, A. J.; Mayewski, Paul Andrew; McGovern, T. H.; Ogilvie, A. E. J.; Sadler, J. P.; and Skidmore, P., "Bioarchaeological and Climatological Evidence for the Fate of Norse Farmers in Medieval Greenland" (1995).

Earth Science Faculty Scholarship. 275.

https://digitalcommons.library.umaine.edu/ers_facpub/275

This Article is brought to you for free and open access by DigitalCommons@UMaine. It has been accepted for inclusion in Earth Science Faculty Scholarship by an authorized administrator of DigitalCommons@UMaine. For more information, please contact

um.library.technical.services@maine.edu. 
Authors

P. C. Buckland, T. Amorosi, L. K. Barlow, A. J. Dugmore, Paul Andrew Mayewski, T. H. McGovern, A. E. J. Ogilvie, J. P. Sadler, and P. Skidmore 


\title{
Bioarchaeological and climatological evidence for the fate of Norse farmers in medieval Greenland
}

\author{
P.C. BuCKLAND, T. AMOROSI, L.K. Barlow, A.J. DugmoRe, \\ P.A. MAYEWSKI, T.H. MCGovern, A.E.J. OGILVIE, J.P. SADLER \\ \& P. SKIDMORE*
}

Greenland, far north land of the Atlantic, has often been beyond the limit of European farming settlement. One of its Norse settlements, colonized just before AD 1000, is astonishingly - not even at the southern tip, but a way up the west coast, the 'Western Settlement'. Environmental studies show why its occupation came to an end within five centuries, leaving Greenland once more a place of Arctic-adapted hunters.

\section{Norse settlement in Greenland}

According to medieval Icelandic sources, the Norse colonization of Greenland begun in $c$. AD 985. Two main areas of settlement were established: the Western Settlement, in the inner fjords east of present-day Nuuk (Godthåb) (FIGURE 1), the modern capital, and the Eastern Settlement at the southern tip of Greenland, near modern Igaliko (Garðar) (Ingstad 1966; Jones 1986). By the end of the 15th century, these Norse colonies had disappeared. This demise has frequently been linked to adverse changes in climate, specifically, the so-called 'Little Ice Age' ( $c f$. Dansgaard et al. 1975; Lamb 1977). There has been much discussion regarding the reality of this climatic event (Grove 1988). Suffice it here to say, although low-temperature events in the latter half of the present millennium are well documented, it is clear that these are neither temporally nor spatially synchronous in all localities of the North Atlantic region. We therefore present the following data without invoking the term 'Little Ice Age', or the connotations surrounding it.
The Western Settlement, in particular, has been a focus of sustained multidisciplinary study, and it is primarily this settlement which is considered here. Some of the findings are compared with proxy climatic data extrapolated from the Greenland Ice Sheet Project (GISP2) ice core. This core was drilled between 1992 and 1993 in central Greenland, in the summit of the ice sheet at $3210 \mathrm{~m}$ above sea level, at lat. $72^{\circ} 28^{\prime} \mathrm{N}$, long. $38^{\circ} 35^{\prime} \mathrm{W}$. The proxy records provided by ice cores have been interpreted as indicators of climatic change. More recently, technological advances, combined with the long stratigraphic integrity of the GISP2 core, have resulted in highly detailed proxy records, which range in timescales from seasons to thousands of years (FIGURE 2). This high level of detail has already given new insights into the climate history of the North Atlantic region (Alley et al. 1993; Mayewski et al. 1993a; 1993b; 1994; Barlow 1994; Zielinski et al. 1994).

Studies, primarily archaeological, historical and anthropological, have shown that, from the start of the Norse settlement in Greenland, sub-

\footnotetext{
* P.C. Buckland \& P. Skidmore, Department of Archaeology \& Prehistory, University of Sheffield, Sheffield S10 2 TN, England. T. Amorosi \& T.H. McGovern, Department of Anthropology, Hunter College, City University of New York, New York NY 10021, USA. L.K. Barlow \& A.E.J. Ogilvie, Institute of Arctic and Alpine Research. University of Colorado, Boulder CO 80309-0410, USA. A.J. Dugmore, Department of Geography, University of Edinburgh, Edinburgh EH8 9хв, Scotland. P.A. Mayewski, Glacier Research Group, Institute for the Study of Earth, Oceans and Space, University of New Hampshire, Durham NH 03824, USA. J.P. Sadler, School of Geography, University of Birmingham, Edgbaston, Birmingham B15 2TT, England.
}

Received 2 May 1995, accepted 27 October 1995.

ANTIQUTTY 70 (1996): 88-96 
FIGURE 1. The distribution of known Norse farm sites in the former Western Settlement area (modern Nuuk district).

Norse farms were restricted to the small areas of richer floral communities in the inner fjord zone of the west coast, where sufficient hay could be collected to overwinter domestic animals. Inuit hunters moved their settlements north and south along the coast to track changes in seamammal abundance. $\mathrm{E}=$ the Norse Eastern Settlement. $\mathrm{Q}=$ the palaeo-Eskimo site of Qeqertasussuk, Disko Bay.

$\mathrm{W}=$ The Norse Western Settlement. Farms where palaeoecological research has been carried out are numbered.

$48=$ Niaquussat. $51=$ Sandnes. $54=$ Nipaatsoq. GUS $=$ the recently discovered site of Gärden under Sandet. Even the most marginal of sites had been occupied by c. AD 1050.

The fjords are indicated by stippling and the inland ice by suitable shading.

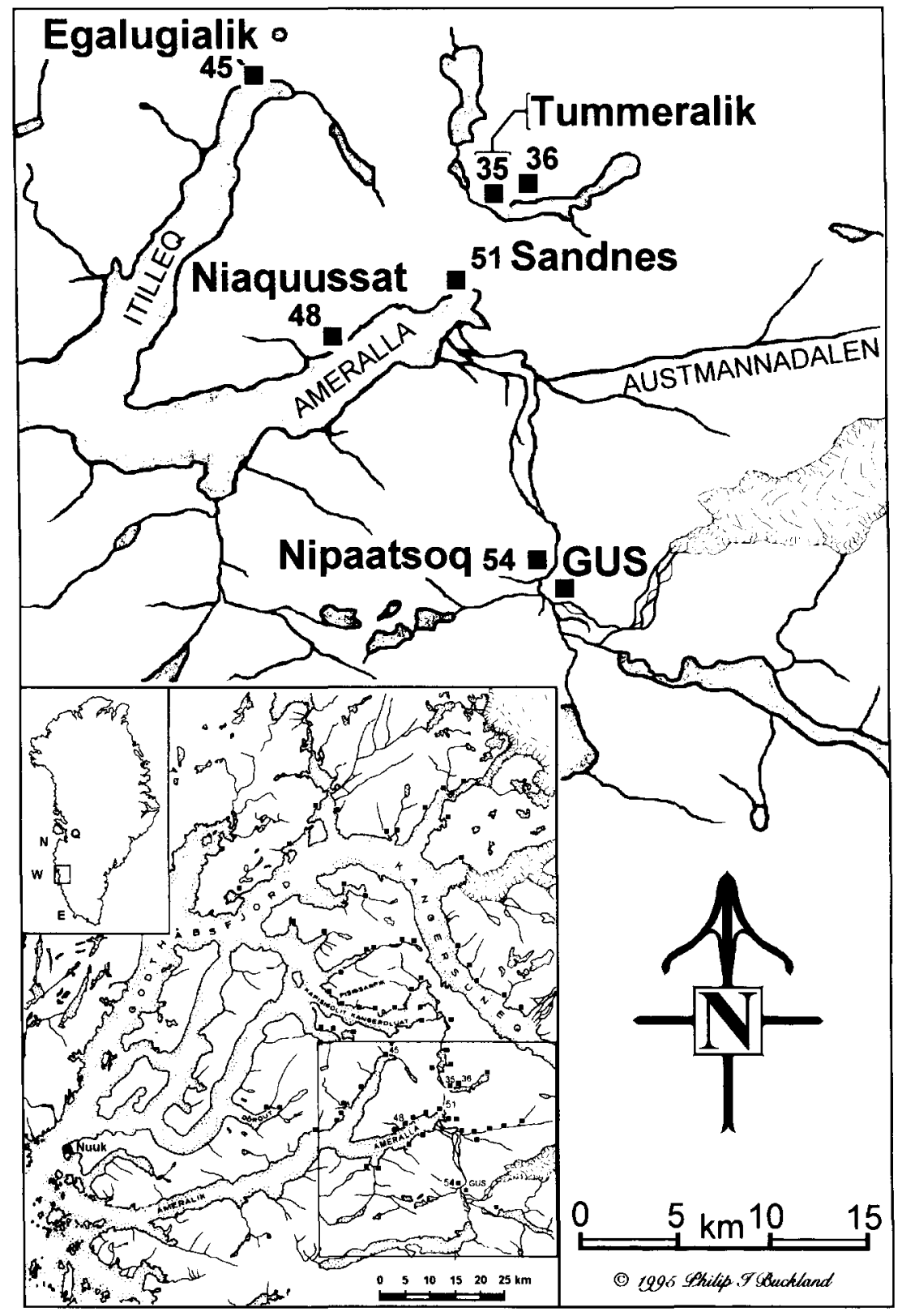

sistence was based upon milk and meat from cattle, sheep and goats (McGovern 1985a) (FIGURE 3). Fossil beetle faunas from the more recently excavated farms in the Western Settlement are dominated by introduced synanthropous elements (Sadler 1991), which lived in stored hay and related habitats. These underline the need for an adequate hay crop to overwinter indoors the domestic stock which could not otherwise survive. Shortfalls in sub- sistence were made up by intensive, largely landbased exploitation of seals and seabirds in the spring, and caribou drives with hunting dogs in the autumn. There is no evidence for any significant domesticated plant-food contribution to the diet, although the seeds of wild fruits, principally crowberry (Empetrum nigrum L.) and bilberry (Vaccinium uliginosum L.) are frequent in samples from the farm middens (McGovern et al. 1983). These core subsistence 

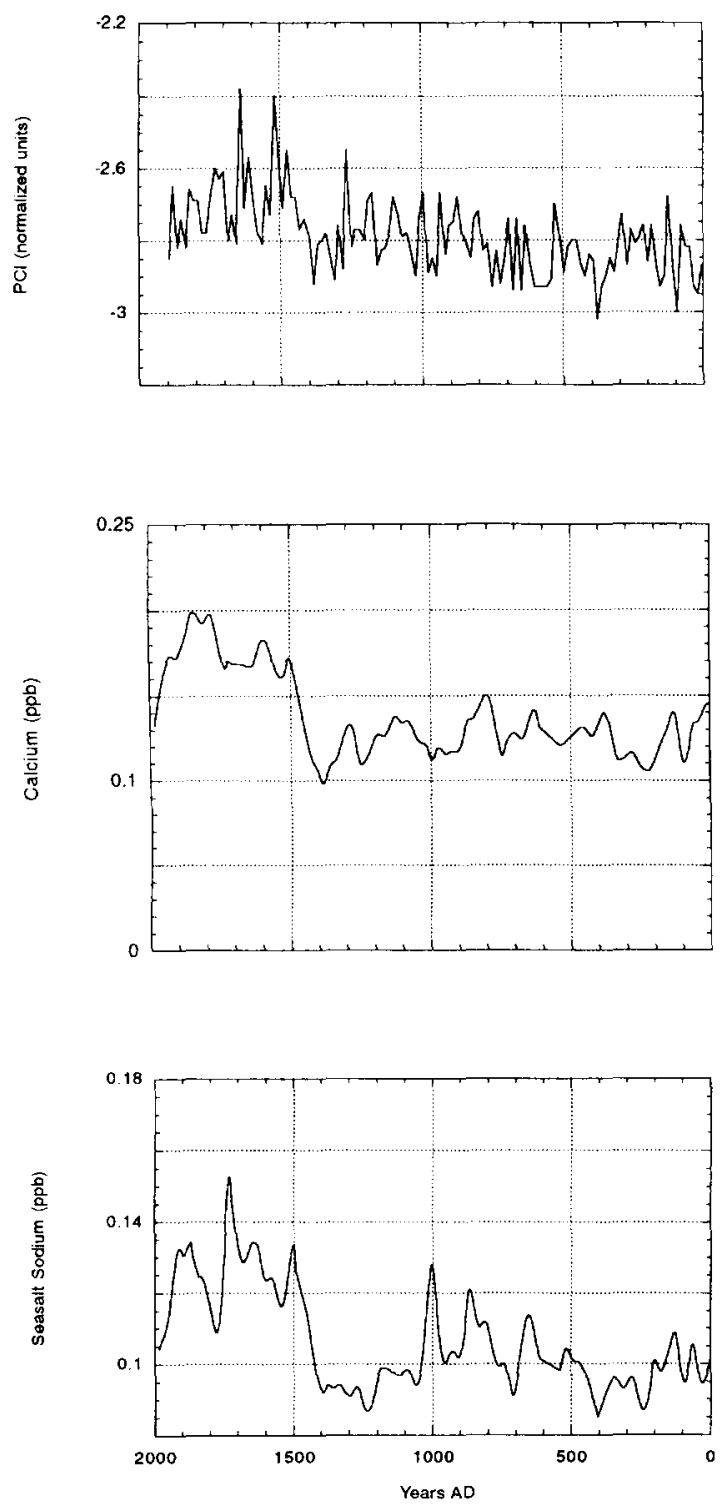

activities required tight co-ordination of communal labour resources and produced little storable surplus. Nevertheless, by 1300 this mixed dairying-hunting society had invested heavily in stone architecture. In the Eastern Settlement, monasteries and parish churches, as well as a cathedral at Garðar (Igaliko) had been built, equipped with imported stained glass and bronze church bells. Stone churches similarly served the Western Settlement (Berglund 1986; 1991; Keller 1991; McGovern 1980). Trade with Europe throughout the period of the set-
FIGURE 2. The record for a range of organic and inorganic input for the last 2000 years in the GISP2 ice core, Greenland.

$P C I$, the Polar Circulation Index, provides a measure of the intensity of polar atmospheric cell circulation in normalized units. A positive increase in value reflects an expansion of the cell. Calcium (Ca) is a measure of atmospheric dustiness in p.p.b., and sea-salt sodium ( $\mathrm{Na}$ ) provides a measure of storminess in the marine environment in p.p.b. The PCI series displayed here is at 4-year resolution, and the calcium and sea-salt sodium are robust spline smooths (approximately 100 year smoothing) of the original biannual data.

The inferred climatic change during the early 15 th century is the most marked in the past 8000 years. The abandonment of the Western Settlement of Norse Greenland took place before this event.

tlement was based on the prestige-goods trade in walrus hide and ivory from animals taken in the Norysetr, some $800 \mathrm{~km}$ north of Nuuk (McGovern 1985a; 1989).

Investigations at the church farm at Sandnes (V51) and surrounding farms have generated important bioarchaeological data (McGovern et al. 1983), with well-preserved organic materials, including bones, dung pellets, lice, fleas, beetles and flies. These data provide additional insights into the nature of the subsistence base and some indications of the final days of the settlement. Many of these data, discussed previously ( $c f$. McGovern et al. 1983; Sveinbjarnardóttir \& Buckland 1983; Buckland \& Sadler 1989), will not be considered in detail here. The principal new line of palaeoecological information is that provided by the fossil flies.

\section{Insect remains in the Greenland sites}

Remains of Coleoptera (beetles), and various ectoparasites of both people and sheep have been the subject of research from a number of Greenland sites (McGovern et al. 1983; Sveinbjarnardóttir \& Buckland 1983; Buckland \& Sadler 1989; Böcher \& Fredskild 1993), but a detailed study of the remains of Diptera, the true flies, has added significantly to the interpretation. Nearly 7000 Dipterous puparia have been examined from the Norse farms, and comparison made with the flies from the pre-European contact palaeo-Eskimo Saqqaq site at Qeqertasussuq, $700 \mathrm{~km}$ to the north (Böcher \& Fredskild 1993). The greater part of the Norse 


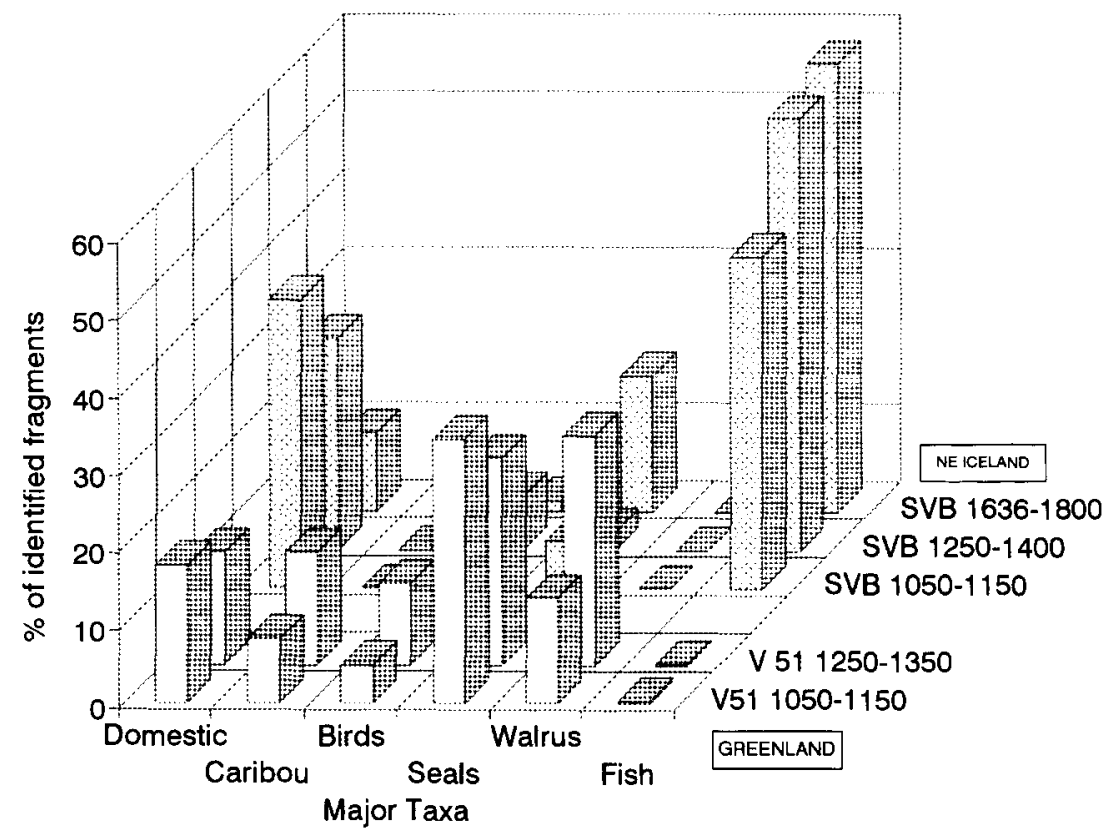

FIGURE 3. A comparison of the animal bone collections from the site of Svalbard (SVB) in pistilfjordur (Amorosi 1992), northeast Iceland and Sandnes (V51) in Ameralla fjord in west Greenland.

Both farms were occupied by $A D$ 1000-1050, and both were church farms playing a central role in their districts. Note the different organization of subsistence and the contrasting roles of walrus and fish in the trading economy. By c. 1050-1150, the Svalbard farm was already involved in intensive fishing, probably entering the growing staples trade in dried fish. By contrast, Sandnes remained a centre for the Viking-age prestige goods trade in walrus products down to its extinction c. 1350. Farmers in the Svalbard district of Iceland appear to have intensified sealing efforts in the 16th-17th centuries, perhaps to compensate for poor hay crops. These might, in turn, have resulted from lowered temperatures associated with changes in climate or an increase in drift ice. The latter is indicated by the appearance of harp seals, including new-born pups, in the bone assemblage (Amorosi 1992).

For a discussion of the effects of sea-ice on grass growth and agriculture, see Fridriksson (1969) and Ogilvie (1982; 1995). Greenlandic farmer/hunters, strongly dependent on seals since first settlement, could have further intensified marine mammal hunting by acquiring Inuit technology; this they failed to do. Svalbard farm, still occupied, remains one of the most prosperous farms in its district.

farm faunas reflect introductions which became extinct along with the farmers. Telomerina flavipes was a thermophilous, troglodytic alien in Greenland and is an excellent indicator of the farms' foetid living-room floors (Buckland et al. 1994). The picture of insanitary conditions, extending throughout the life of the settlements, however, differs little from contemporary Dublin or York ( $c f$. Coope 1981; Hall et al. 1983). The dominant element in the fly fauna $(>81 \%)$ is necrophilous in the larval state. Even on the middens, the assemblages are clearly those which have bred indoors in carrion, including faeces with animal protein, in the warmer parts of the buildings. Those taxa which breed out- doors in carrion, including the Piophilid flies characteristic of fat and bone marrow accumulations, are virtually absent. In contrast, the evidence from the palaeo-Eskimo site (TABLE 1) indicates that meat and fat were routinely left unused there. Animal-bone collections from medieval Icelandic and Greenlandic sites indicate a far greater degree of fragmentation for marrow-fat extraction in the Norse Greenlandic materials. While both palaeo-Eskimo and Norse Greenlanders lacked substantial carbohydrate sources and had to consume more fat to allow effective protein metabolism (Speth 1991), the Norse farmers evidently had to process their kills far more completely than the palaeo-Eskimos. 


\section{Heleomyza ?Scoliocentra Telomerina Piophilidae CalliphoraPhormia}

$\begin{array}{lllll}\text { spp } & \text { sp. } & \text { flavipes } & \text { sp. }\end{array}$

1 site/group of sites

Norse Western Settlement

Inuit midden, Qeqertasassuk

$\begin{array}{ll}* & + \\ + & 0\end{array}$

\section{2 light tolerance}

exophilic

endophilic

3 thermal tolerance

highly cold resistant

thermophilous

$+$

$\overline{\mathrm{P}}$

$\begin{array}{llll}* & + & 0 & 0 \\ 0 & * & * & * \\ - & P & t & P \\ P & - & t & \end{array}$

4 materials

pure carrion and bone marrow
dung, some animal protein content

$\begin{array}{llllll}t & t & - & t & t & t \\ t & t & P & t & t & t\end{array}$

5 colonization wave

early colonizer

late colonizer

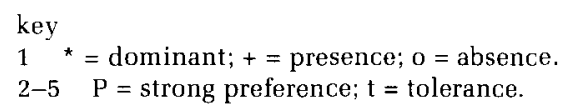

Notes

a Certain Piophilids (e.g. Lasiopiophila pilosa, Phormia atriceps and, to a lesser degree, Calliphora uralensis) have strong preference for colder climates, the first two being essentially High Arctic species.

b In the entire Western Settlement count of 6915 Dipterous remains, Piophilids are as follows: Allopiophila vulgaris 135, Lasiopiophila pilosa 1.

c At Qeqertasussuk, the same species are P. vulgaris 617, L. pilosa 229. These results would be expected from a High Arctic site.

TABLE 1. The necrophagous flies of Greenland.

\section{Sandnes}

stercoricolous (herbivore dung, e.g. Scathophaga furcata) endophilic coprophages/necrophages (e.g. Heleomyza/Telomerina spp.) exophilic necrophages (e.g. Piophilidae, Calliphoridae) phytophages (e.g. Agromyzidae, Delia, Botanophila, Pegomya spp.) algaecoles (e.g. Ephydridae, Zaphne, Spilogona spp.) fucicoles (Orygma, Fucellia spp.)

ripicoles (e.g. adults only of Simulium spp.)

humicoles (e.g. Phaonia, Tipula spp.)

ectoparasitic (Melophagus ovinus on sheep)

$\begin{array}{rc}114 & 1 \\ 1424 & - \\ 8 & 1897^{\star} \\ 176 & 69 \\ 180 & 18 \\ 9 & 203 \\ 52 & - \\ 2 & 2 \\ 8 & - \\ 1974 & 2198\end{array}$

spp.

Qeqertasussuk

* includes 486 individuals of Heleomyza borealis, which will breed in an unshaded situation.

TABLE 1b. Absolute numbers of identified Diptera from Sandnes, the Norse farm site at Sandnes, Ameralla, Greenland, compared with the Saqqaq palaeo-Eskimo site at Qeqertasussuk, Disko Bay, Greenland. 


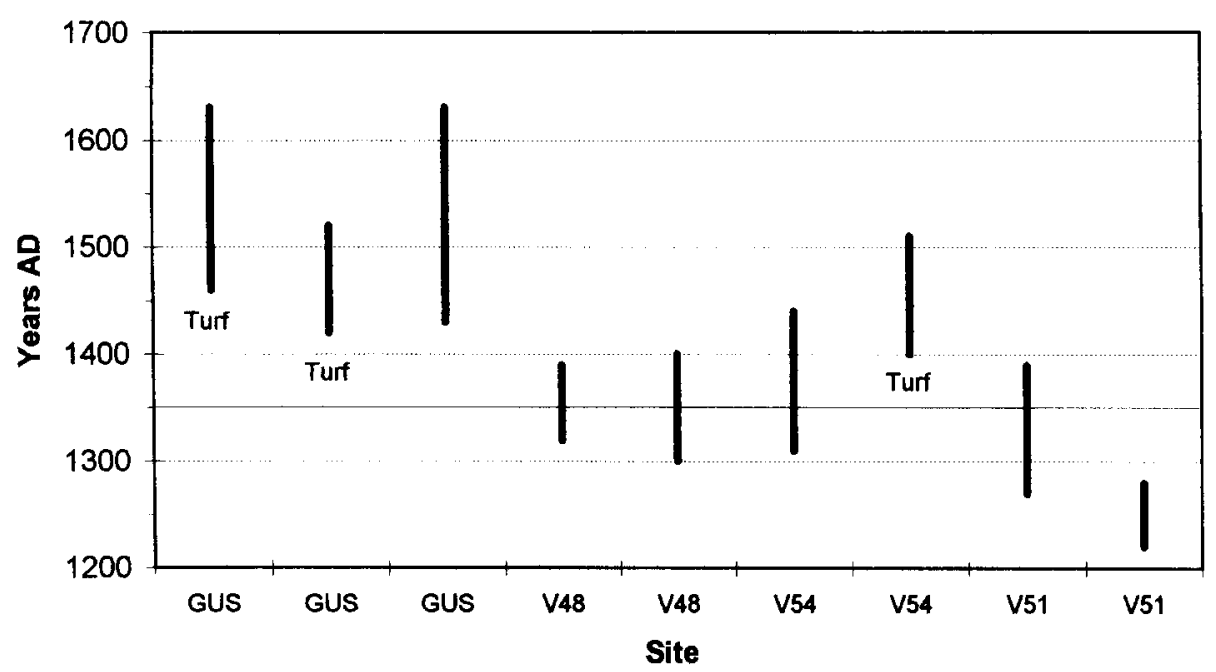

FIGURE 4. Calibrated radiocarbon dates ( $1 \sigma$ range) for the abandonment of farms in medieval Greenland.

Documentary sources suggest a terminal date of c. 1350-1360 for the Western settlements (Ogilvie 1996). Radiocarbon assay supports this date range for desertion. Some dates are on turf growing over the ruins.

The moderate-sized farms of GUS (Andreasen \& Arneborg 1992; 1993) and V54 (MCGovern et al. 1983) (see FIGURE 1) are near-neighbours; V48 (MCGovern et al. 1983) was a small fjord-side farm, whilst V51 (Sandnes) was the largest in the district, with a church (Roussell 1936). Although the number of available dates remains small (TABLE 2), all sites appear to have been abandoned in the mid 14th century. The radiocarbon dates have been calibrated using Oxcal (Ramsey 1994).

\begin{tabular}{|c|c|c|c|c|c|c|c|}
\hline site & context & material & lab. no. & $\begin{array}{c}\text { uncalibrated } \\
\text { determination b.p. }\end{array}$ & $\begin{array}{r}\text { dat } \\
\text { lower }\end{array}$ & $\begin{array}{l}\text { e AD } \\
\text { upper }\end{array}$ & reference \\
\hline GUS & $\begin{array}{l}\text { turf over } \\
\text { structure }\end{array}$ & peat & $\mathrm{K}-5821$ & $360 \pm 55$ & 1460 & 1630 & $\begin{array}{l}\text { Andreasen \& } \\
\text { Arneborg } 1992\end{array}$ \\
\hline GUS & $\begin{array}{l}\text { turf over } \\
\text { structure }\end{array}$ & peat & K-5822 & $415 \pm 55$ & 1420 & 1520 & $\begin{array}{l}\text { Andreasen \& } \\
\text { Arneborg } 1992\end{array}$ \\
\hline GUS & $\begin{array}{l}\text { over } \\
\text { structure }\end{array}$ & antler & K-5823 & $395 \pm 50$ & 1430 & 1630 & $\begin{array}{l}\text { Andreasen \& } \\
\text { Arneborg } 1992\end{array}$ \\
\hline V 48 & latest phase & $\begin{array}{l}\text { terrestrial } \\
\text { mammal bone }\end{array}$ & K-3201 & $640 \pm 50$ & 1320 & 1390 & $\begin{array}{l}\text { McGovern } \\
\text { et al. } 1983\end{array}$ \\
\hline V 48 & latest phase & $\begin{array}{l}\text { terrestrial } \\
\text { mammal bone }\end{array}$ & $\mathrm{K}-3203$ & $610 \pm 50$ & 1300 & 1400 & $\begin{array}{l}\text { McGovern } \\
\text { et al. } 1983\end{array}$ \\
\hline V54 & $\begin{array}{l}\text { turf over } \\
\text { structure }\end{array}$ & $\begin{array}{l}\text { peat/ } \\
\text { willow charcoal }\end{array}$ & $\mathrm{K}-3062$ & $540 \pm 50$ & 1310 & 1440 & Andreasen 1982 \\
\hline V54 & $\begin{array}{l}\text { turf over } \\
\text { structure }\end{array}$ & peat & $\mathrm{K}-3061$ & $450 \pm 65$ & 1400 & 1510 & Andreasen 1982 \\
\hline V51 & late phase & caribou bone & $K-4605$ & $670 \pm 50$ & 1270 & 1390 & $\begin{array}{l}\text { McGovern } \\
\text { unpublished }\end{array}$ \\
\hline V51 & late phase & cattle bone & K-4606 & $760 \pm 50$ & 1220 & 1280 & $\begin{array}{l}\text { McGovern } \\
\text { unpublished }\end{array}$ \\
\hline
\end{tabular}

Calibration is after Ramsey (1994) using OxCal Calibration Program.

TABLE 2, Radiocarbon dates for the terminal phases of farms in the Western Settlement, Greenland. 
Thule culture Inuit hunters, who came to Greenland from Ellesmere Island around $\mathrm{AD}$ 1100 , were in direct contact with the Norse for nearly 300 years (McGovern 1985b). In spite of this, the Norse failed to emulate their example and did not acquire sophisticated skin clothing, harpoons and suitable equipment for hunting out on the sea ice. They were therefore unable to expand their sea-mammal hunting to include ringed seals and the great whales. The virtual absence of fish remains and fishing equipment, and indications from the bone evidence that most common seals were taken on their pupping areas, serves to emphasize further the limits of maritime adaptation amongst the Norse Greenlanders. Despite some evidence of seaweed (Buckland et al. 1993), isotopic ratios indicate little intake of marine products by domestic animals. While contact with the Thule Inuit appears to have been deliberately restricted (McGovern 1985b), the Norse economy seems to have stagnated. Tied to the limited pastures of the southwest, it was increasingly isolated from continental markets by a declining demand for walrus ivory and other changes in trading conditions (CarusWilson 1933). Furthermore, a possible increase in drift ice could have made sailing more hazardous (Ogilvie 1991; 1996). Norse society in the early 14th century had created a disastrous vulnerability to any curtailment in growing season and pasture productivity.

Although the number of radiocarbon dates from sites in Ameralla remains small (FIGURE 4 \& TABLE 2), they appear to indicate desertion by the middle of the 14 th century, during an apparently minor cooling event in the ice core record (FIGURE 2). This accords well with the documentary evidence (Ogilvie 1996). In a landscape where all available timber would be reused, doors and roofs were left to collapse onto floors as farms decayed. The end is graphically indicated at the small farm at Nipaatsoq (McGovern et al. 1983), at the middle-rank farm at Tummeralik, and at the large farm Sandnes at the head of the fjord (Degerbøl 1936). The final floor layers at each farm contained the partly articulated remains of Norse hunting dogs, some displaying cut-marks indicating butchery. The minimum number of dogs killed at Sandnes (V51) was nine, Tummeralik (V35) three and Nipaatsoq (V54) two. The implication is that this butchery was a desperate act that destroyed future ability to hunt effectively. The fly faunas from a room interpreted as the bedroom at Nipaatsoq mirror the end as a thermophilous indoor fauna is replaced by a cold one and finally by outdoor species as the roof collapses. There is also hint in the faunas of other stresses. The Anthomyid fly Delia fabricii (Holm.), which breeds in the meadow grass Poa pratensis L., is often abundant in samples from other Norse farms; it is absent in the final floors at Nipaatsoq. This could be interpreted in terms of poorer, less grass-rich hay yields as the farmers desperately sought to maintain their livestock. The recent discovery of a frozen Norse farm neighbouring Nipaatsoq, containing large amounts of well-preserved wood further confirms the impression of a sudden and final end to the Western Settlement (Andreasen \& Arneborg 1992; Arneborg \& Berglund 1993) and offers further opportunities to study the demise of a farm.

\section{Climate and settlement in medieval Greenland}

The GISP2 ice-core documents at least two sets of proxy climatic parameters which are important for the study of Norse settlements in Greenland. Several environmental indicators, including calcium and sea-salt sodium, demonstrate the most abrupt and the largest change of the last 8000 years between $\mathrm{AD} 1400$ and 1420 (FIGURE 2). Increased calcium concentrations provide evidence of stronger circulation over continental regions and the presence of more easily eroded soils, suggesting a response to cooler climates and reduced vegetation cover, while increased sea-salt sodium is interpreted as resulting from intensification of marine storminess and increased cyclogenesis (Mayewski et al. 1993b). Both parameters suggest a change in atmospheric circulation patterns which persists into the 20th century (FIGURE 2). Isotopic signals of deuterium and oxygen from Greenland ice cores suggest that overall the 14th century was lower in temperature than the 15th century in central Greenland (Dansgaard et al. 1975; Barlow et al. 1993). Seasonally resolved isotopic records suggest clusters of low-temperature time-periods. Among these are $A D 1308$ to 1319 , representing the longest time-period of low winter values until the $1560 \mathrm{~s}$, and a 20-year time-period of low summer values between AD 1343 and 1362 (Barlow 1994). 
Climatic regimes in Iceland and Greenland are by no means the same. However, the historical climatic record from Iceland may help to increase our understanding of events in Norse Greenland. We know from the Icelandic record that the 14th century was a period of considerable climatic instability. Furthermore, there is clear evidence for cold conditions and hardship amongst people during the mid to late 14 th century. The early 15th century, however, appears to have been mild (Ogilvie 1991). Knowledge of what occurred in Iceland during years of grass failure may also cast light on what happened in Greenland; these invariably led to deaths amongst the livestock and frequently to human mortality and desertion of farms (Ogilvie 1984). In Iceland, many landholders increasingly integrated their subsistence with the European urban demand for fish (Amorosi et al. 1994). In contrast, Greenland's connections with Europe remained tied to the luxury goods trade in walrus hide and ivory (FIGURE 3 ).

Throughout Europe, the 14th century was a period of population decline and settlement retrenchment ( $c f$. Kershaw 1973; Abel 1980). The role of climate in these events is controversial and the same may be said for Greenland. The new GISP2 ice- core data indicate that the extinction of the Western Settlement pre-dated the most profound changes in atmospheric circulation, but also show that multi-year stretches of low-temperature seasons occurred during the 14th century. In a system heavily dependant upon the harvesting of sufficient hay to overwinter domestic animals, a concentration of closely spaced cool and wet summers followed by cold winters or springs could have been sufficient to trigger widespread abandonment. Certainly, all the bioarchaeological evidence from the Norse sites indicates the precarious nature of their subsistence. This vulnerability was exacerbated by a conservative social system, wider economic changes and activities which degraded the very parts of the ecosystem upon which they depended (Fredskild 1988; 1992; Jacobsen 1991). While climate change certainly made Greenland far less habitable for the Norse, even the coldest parts of the post-medieval period failed to interfere with Inuit settlement and subsistence. When John Davis and other 16th-century voyagers explored Greenland, they found only arctic-adapted hunters.

Acknowledgements. This work forms part of a NABO (North Atlantic Biocultural Organisation) project funded by the National Science Foundation (USA), Office of Polar Programs, ARCSS Program and the US Global Change Program. Thanks are due to the National Museum and Archives of Greenland and the Museum \& Art Gallery, Doncaster, England. Excavations in the Western Settlement, from which samples have been studied, were also directed by Claus Andreasen, Jette Arneborg and Joel Berglund, who, along with Bent Fredskild, freely gave of their expertise in this interpretation. Jens Böcher kindly made material available from the palaeo-Eskimo site at Qeqertasussuq. Diagrams are the work of Philip I. Buckland. The authors also wish to thank Kevin Edwards, Julian Henderson, Mjöll Snæesdóttir and an un-named referee for comments upon the text. The initial study of entomological material from sites in the Western Settlement was supported by the Leverhulme Trust (Grant no. F94M) (UK). Astrid Ogilvie wishes to acknowledge the support of the Leverhulme Trust (Grant no. F204L) and the National Science Foundation, USA, ARCSS Program (Grant no. OPP-9418845). Lisa Barlow is supported by this NSF ARCSS Program grant and formerly an additional NSF grant supporting the GISP2 project.

\section{References}

ABEL, W. 1980. Agricultural fluctuations in Europe from the 13th to the 20th century. London: Methuen.

Alley, R.B., D. MEESE, C.A. SHUMan, A.J. GOW, K. TAYLOR, M RAM, E.D. WAdDInGTON \& P.A. MaYEWSKI. 1993. Abrupt accumulation increase at the Younger Dryas termination in the GISP2 ice core, Nature 362: 527-9.

Amorosi, T. 1992. Climate impact and human response in Northeast Iceland: archaeological investigations at Svalbar $\partial$ 1986-1988, in C.D. Morris \& D.J. Rackham (ed.), Norse and later settlement and subsistence in the North Atlantic: 103-38. Glasgow: University of Glasgow.

ANDREASEN, C. 1982. Nipaitsoq og Vesterbygden på Grønland Tidsskriftet Gronland 5-6-7: 177-88.

ANDREAsen, C. \& J. ARneBorg. 1992a. Gården under Sandet undersøgelserne 1991, Forskning $i$ Gronland/tusaat 1/ 92: $10-18$

1992b. Gården under sandet - nye nordboundersøgelser I Vesterbygden, Gronlandsk Kultur-og Samfunds Forskning 92: $11-50$.
ARnEBORG, J. \& J. BERGLUND. 1993. Gården under Sandet, Forskning i Gronland/tusaat 4/93: 7-19.

BARLOW, L.K. 1994. Evaluation of seasonal to decadal scale deuterium and deuterium excess signals, GISP2 ice core, Summit, Greenland, AD 1270-1985. Unpublished Ph.D dissertation, University of Colorado.

BARLow, L.K., J.W.C. WhITE, S. JOHNSON, J. JOUZEL. \& P.M. GROOTES. 1993. Climate variability during the last 1000 years from delta Deuterium and delta ${ }^{18} \mathrm{O}$ in the GISP2 and GRIP deep ice cores, EOS, Transactions of the American Geophysical Union, Fall Meeting Supplement (1993): 118.

BERGLUND, J, 1986. The decline of the Norse settlements in Greenland, Arctic Anthropology 23: 109-37.

1991. Displacements in the building-over of the Eastern Settlement, Greenland, Acta Archaeologia 61: 151-7.

BÖCHER. J. \& B. FREDSKILD. 1993. Plant and arthropod remains from the palaeo-Eskimo site on Qeqertasussuk, West Greenland, Meddelelser om Gronland, Geoscience 30. 
BUCKLAND, P.C. \& J.P. SADLER, 1989. A biogeography of the human flea Pulex irrifans L. (Siphonaptera: Pulicidae), Journal of Biogeography 16: 115-20.

BuCKLAND, P.C., J.P. SADLER \& D. SMITH. 1993. An insect's eyeview of the Norse farm, in C.E. Batey et al. (ed.), The Viking Age in Caithness. Orkney and the North Atlantic: 518-28. Edinburgh: Edinburgh University Press.

Buckland, P.C., T.H. Mccovern, J.P. SAdLeR \& P. SKIDMORE. 1994. Twig layers, floors and middens: recent palaeoecological research in the Western Settlement. Greenland, in B. Ambrosiani \& H. Clarke (ed.), Proceedings of the XII Viking Congress, Stockholm: 132-43. Stockholm: Birka Project. Birka Studies 3.

CARUS-WILson, E.M. 1933. The Iceland Trade, in E. Power \& M.M. Postan (ed.), Studies in English trade in the 15th century: 155-82. London: Routledge \& Kegan Paul.

COOPE, G.R. 1981. Report on the Coleoptera from an 11thcentury house at Christ Church Place, Dublin, in H. Bekker-Nielson et al. (ed.), Proceedings of the Eighth Viking Congress (1977): 51-6. Odense: Odense University Press.

Dansciart, W., S.J. Johnsen, N. Reeh, N. Gundestrup, H.B. Clausen \& C.U. Hammer, 1975. Climatic changes, Norsemen, and modern man, Nature 255: 24-8.

DEcerBøL, M. 1936. The animal bone, in Roussell (1936).

FREDSKILD, B. 1988. Agriculture in a marginal area: South Greenland AD 985-1985, in H.H. Birks et al. (ed.), The cultural landscape past, present. and future: 381-93. Cambridge: Cambridge University Press.

1992. Erosion and vegetation changes in south Greenland caused by agriculture, Geografisk Tidsskrift 92: 14-21.

FRIĐRIKSSON, S. 1969. The effects of sea ice on flora, fauna and agriculture, Jökull 19: 146-57

Grovi:, J.M. 1988. The Little Ice Age. London: Methuen.

Hall, A.R., H.K. Kenward, D. WILliams \& I.R.A. GrEIG. 1983. Environment and living conditions at two Anglo-Scandinavian sites. London: Council for British Archaeology. Archaeology of York 14/4.

INGSTAD, H. 1966. Land under the Pole Star. London: Jonathan Cape.

JACOBSEN, B.H. 1991. Soil resources and soil erosion in the Norse settlement area of Østerbygden in southern Greenland, Acta Borealia 1: 56-68.

Jones, G. 1986. The Norse Atlantic saga. 2nd edition. Oxford: Oxford University Press.

KELler, C. 1991. Vikings in the West Atlantic: a model of Norse Greenlandic medieval society, Acta Archaeologia 61: $126-41$

KERSHAW, I. 1973. The great famine and agrarian crisis in England, 1315-1322, Past \& Present 59: 1-50.

LAMB, H.H. 1977. Climate: present, past and future 2. Climatic history and the future. London: Methuen.

MCGOVERN, T.H. 1980. Cows, harp seals, and churchbells: adaptation and extinction in Norse Greenland, Human Ecology 8: 245-75.

1985a. Contributions to the palaeoeconomy of Norse Greenland, Acto Archaeologia 54: 73-141.

1985b. The Arctic frontier of Norse Greenland, in $S$. Green \& S. Pearlman (ed.), The archaeology of frontiers and boundaries: 275-323. New York (NY): Academic Press.

1989. Bones, buildings, and boundaries: patterns in Greenlandic palaeoeconomy, Acta Archaeologia 59: 71-122.
MCGOVERN, T.H., G.F. BIGLLOW, T. AMOROSI \& D. RLSSILLI. 1988. Northern islands, human error, and environmental degradation: a view of social and ecological change in the medieval North Atlantic, Human Ecology 16(3): 225-70.

M(GOVERN, T.H., P.C. BUCKL.AND. D. SAVORY, G. SVEINBJARNARDótTiR, C. ANDREASEn \& P. SKIDMORE. 1983. A study of the faunal and floral remains from two Norse farms in the Western Settlement, Greenland, Arctic Anthropology 20: 93-120.

MAYFWSki, P.A., L.D. MEEKER, S. WhITLOW, M.S. TWICKLER, M.C. MORRISON, R.B. ALILY, P. BLOOMFIELD \& K. TAYLOR. 1993a. The atmosphere during the Younger Dryas, Science 261: 195-7.

MAYEWSKI, P.A., L.D. MEEKER, M.C. MORRISON, M.S. TWICKLER, S. WhitLOW, D.A. FERLAND. D. MEESF, M.R. LIGGRANI) \& J.P. STEFFENSON. 1993b. Greenland ice core 'signal' characteristics: an expanded view of climate change, lournal of Geophysical Research 98 (D7): 12839-47.

MAYEWSKJ, P.A., L.D. MEEKER, S. WHITLOW, M.S. TWICKLER, M.C. Morrison, P.M. Grootes, G.C. Bond, R.B. Alı.EY, D.A. MEESE, A.J. GOW, K.C. TAYLOR, M. RAM \& M. WUMKES. 1994. Changes in atmospheric circulation and ocean ice cover over the North Atlantic during the last 41,000 years. Science 263: 1747-51.

OgILviE, A.E.J. 1982. Climate and society in Iceland from the medieval period to the late 18 th century. Unpublished Ph.D dissertation, University of East Anglia.

1984. The impact of climate on grass growth and hay yield in Iceland: AD 1601 to 1780 , in N.A. Mörner \& W.Karlén (ed.). Climatic changes on a yearly to millennial basis: 343-52. Dordrecht: Reidel.

1991. Climatic changes in Iceland AD c. 865 to 1598 . Acto Archaeologia 61: 233-51.

1995. 'The country's ancient enemy': sea-ice variations in Iceland in historical times and their social impact, in $\mathrm{P}$. Heikinheimo (ed.), Proceedings of the SILMO Conference, International conference on past, present and future climate, Helsinki, Finland, 22-25 August, 1995: 176-8. Helsinki: Academy of Finland 6/95.

1996. Historical accounts of weather events and other related matters in Iceland and Greenland, AD c. 1250-1430, in B. Frenzel (ed.), Documentary climate information for 1750-1850 and the 14th century. Stuttgart: European Science Foundation \& Academy of Science and Literature, Mainz. Paloeoclimate Research - Paläokilaforschungen 9.

RAMSEY, C.B. 1994. Oxcal. v. 2.14: radiocarbon calibration and statistical analysis program. Oxford: Research Laboratory for Archaeology.

Rousselt, A. 1936. Sandnes and the neighbouring farms, Meddelelser om Gronland 88(3).

SADLER, J. 1991. Beetles, boats and biogeography. Insect invaders of the North Atlantic, Acta Archaeologia 61: 199-211.

SPETH, J. 1991. Protein selection and avoidance strategies of contemporary and ancestral foragers: unresolved issues, Philosophical Transactions of the Royal Society of London B 334: 265-70.

SveINBJARNARDótTIR, G. \& P.C. BuICKLAND. 1983. An uninvited guest, Antiquity 48: 127-30.

ZieLinSKI, G.A., P.A. MaYewski, L.D. MeEkER, S.I. WhITLUW, M.S. TWicki.ER, M.C. Morrison. D. MeEse, R. Alley \& A.J. Gow. 1994. Record of volcanism since $7000 \mathrm{BC}$, from the GISP2 Greenland ice core and implications for the volcano-climate system, Science 26: 948-52. 